\title{
Influence of Devolved Financial Resource Governance Structure on Service Delivery in Public Health Sector in Kenya
}

\author{
Lawrence Asidaga Masaviru* \\ School of Entrepreneurship and Procurement Management \\ JKUAT, Kenya \\ Prof. Gregory Simiyu Namusonge (PhD) \\ School of Entrepreneurship and Procurement Management \\ JKUAT, Kenya \\ Dr. Elizabeth Makokha Nambuswa (PhD) \\ School of Entrepreneurship and Procurement Management \\ JKUAT, Kenya
}

\begin{abstract}
The purpose of the study was to establish the relationship between implementation of devolved financial resource governance structure and service delivery in the public health sector of the County government of Trans Nzoia, Kenya. The study was anchored on sequential theory of decentralization and adopted embedded mixed methods research design. The target population was 663 respondents comprising of 15 hospital administrators, 16 doctors, 50 clinical officers, 240 nurses and 342 patient care givers in all the 74 public health care facilities in the County government of Trans Nzoia. Stratified random sampling technique was used to select 331 respondents comprising of 8 administrators, 8 doctors, 19 clinical officers, 148 nurses and 148 patient care givers were sampled from 74 public health facilities for study. Data was collected using questionnaires, checklist and document analysis guide. Validity of data collection instruments was determined by experts and peers, and the tool modified accordingly after a pilot study in the neighboring Bungoma County. Reliability was established using test Cronbach Alpha technique. Both descriptive and inferential statistics were used in data analysis with the help of SPSS program version 21. Descriptive statistics involved frequencies, percentages, means and standard deviation, while inferential statistics involved the use of Spearman Rank Order Correlation, simple linear and multiple regressions. Data was presented using tables. The study established that health care service delivery was not satisfactory and that devolved financial resource governance structure had not been fully implemented. The study established a positive relationship between implementation of devolved financial resource governance structure and service delivery in the public health sector. The study recommended for adequate revenue allocation, timely disbursement and own revenue generation by county governments. The study also recommended for annual audits to ensure effective and efficient use of financial resources.
\end{abstract}

Keywords: Devolved financial governance structure, service delivery in the health sector

DOI: $10.7176 /$ PPAR/11-1-03

Publication date: January $31^{\text {st }} 2021$

\subsection{INTRODUCTION}

Financial decentralization refers to a set of policies aimed at increasing the revenues or financial autonomy of sub national governments and it involves the devolution of financial resources and revenue generating powers. It is said to exist when sub national governments have decision-making powers to raise revenue and perform spending activities (Kim, 2008). Wagana, Iravo and Nzulwa (2016) argued that this is the most traceable type of decentralization as it is directly linked to budgetary processes. It necessitates the transfer of powers to raise and retain resources. Different countries in the world over have adopted different forms of decentralization to enhance service delivery in the health sector. Canadian government for instance is known to be one of the leading countries in the world with an excellent devolved healthcare system. The system is universal, guided by the Canadian Healthcare Act of 1984. The Act provides for a decentralized universal, publicly funded health system, called Canadian Medicare. Healthcare is funded and administered specifically by the country's confederation consisting of the ten provinces and three territories. These administrative units are responsible for primary healthcare and management of hospitals and other related institutions, by setting budgets and financing schedules with health professionals. Each province and territory receives cash assistance from the federal government on a per capita basis.

Universal healthcare is available to Canadian citizens, including permanent residents who are compelled to have public health insurance. Nearly all healthcare services, including emergency, are free in all provinces, on condition that one posses a medical insurance certificate. Patients are allowed to consult any doctor, whether private or public, since consultation fees are standardized. Universal healthcare means that all people have access 
to health services they need (preventive, treatment, rehabilitation and palliative care) without the risk of financial hardship at the time of treatment. The National Insurance scheme takes care of all their medical expenses. Medicare is designed to be universal, portable, comprehensive, accessible, publicly administered and mostly free at the point of use. Universality, accessibility and comprehensiveness are assured through the principle that "all ensured" persons are to be provided with necessary healthcare, on the basis of need rather than ability to pay (Bridgood, 2013).

In the Netherlands, the government has put a lot of emphasis on health financing in its devolved health sector. Netherlands health expenditure has been rising steadily and always above European Union average. For instance, in 2013, health spending amounted to $12.9 \%$ of the GDP in the Netherlands and was the highest in Europe (WHO, 2015). The Dutch health care system is financed by compulsory contributions and premiums. All Dutch citizens since 2006 are compulsorily insured for curative health care under the insurance health Act. The Act provides a basic benefit package, including all care that is considered to be essential, efficient and unaffordable by individual citizens. People aged 18 years and above have to purchase a health insurance plan from health insurers and pay provisions directly to the insurer of their choice.

In Sub Saharan Africa, many countries face a number of challenges with regard to access to quality public health care (WHO, 2014). Consequently, the need for a strong health care system and work force that can deliver health care services reliably and consistently cannot be underscored. As a remedy, most countries have adopted different forms of decentralization to enhance service delivery. Devolved system was aimed at addressing the financial, managerial, operational and political issues which resulted in systemic inefficiencies in the health sector. In South Africa, the government has transferred several functions from central government to local governments, with a view to improving service delivery in key functions, including health. South Africa's devolution model has so far reached the provincial level but is yet to cascade down to lower levels of governance. According to Barker, Malaki, Mwai and Dutta (2014), the health system in South Africa is already structured with significant level of decentralization.

In Kenya, implementation of the 2010 constitution created two levels of government on equal basis namely; the county and national governments. Despite the two levels, Kenya remains a unitary state. The Constitution, under Article 6(1), divides Kenya into 47 counties as specified in the First Schedule, each with clearly defined geographical boundaries established by the Independence Electoral and Boundaries Commission (IEBC). The two levels are distinct but inter-dependent and work in harmony. They consult and cooperate with each other, while accepting the fact that neither the national nor the county government is superior to the other. Each level of government has powers to acquire and secure resources, and that all institutions established under them are required by the Constitution to ensure involvement of the citizens in their affairs through public participation. Each one of the levels of government has representatives who are democratically elected and have autonomous political authority. These include representatives for Senate, National Assembly, the President, the County Assembly and the Governor in each of the 47 Counties.

The county governments have constitutional authority to make and enforce local legislation. Citizens are entitled to have equal access to resources at either level of government. Just like the National government, County governments are based on democratic principles and separation of powers between the executive and the legislative arms. The structures specified in the County Governments Act, starting from the top are, the County Executive Committee, headed by the Governor, under which the Executive Committee Members fall; The Sub-County (which is the same as the electoral constituency for members of parliament), headed by a Sub-County Administrator; The Ward, level represented by an elected member of the county assembly (MCA) and headed by a ward administrator who coordinates development and service delivery activities; Village level, headed by the Village Administrator, who works with the Village Council with the main role of coordinating development activities within the village and ensuring citizen participation. The County Government may, in line with Section 54(1) of the County Governments Act, 2012, decentralize further, below the village level.

The Constitution of Kenya, under Article 179, vests executive authority of the county in the County Executive Committee, which consists of the Governor, who chairs the Executive Committee meetings, the Deputy Governor and up ten Executive Committee members, who head County Departments. Governors structure their respective county departments based on the devolved functions and their areas of focus. In Trans Nzoia the ten Departments are, Finance; Health Services; Public Service Management; Transport and Infrastructure; Lands, Housing and Urban Development; Water, Environment and Natural Resources; Education; Agriculture, Livestock, Fisheries and Cooperatives; Economic Planning, Commerce and Industry; Gender, Sports, Culture and Tourism. Executive Committee Members are assigned functions in their respective departments bearing in mind that they have collective responsibility. As part of Executive Committee, we have the County Secretary who records the deliberations of the Committee and disseminates decisions taken to the departments for action. Below the Executive Committee Members are Chief Officers responsible for administration and service delivery, up to the lowest unit, in their respective departments. This explains why departments are referred to as devolved structures in this study. 
Various empirical evidence point out to the importance of leadership and governance in the health sector. Kelora \& Osoe, (2015), for instance, studied the role of good governance structures in enhancing service provision for social and economic development in counties in Kenya. From these findings, the study established that governance structures play a key role in enhancing service provision. The study recommended that as county governments embrace strategic management processes for sustainable economic growth and service delivery, they should adopt lean management structures for more effective and efficient management of county departments and institutions. It also recommended that counties should focus on determining important structures which match their various strategies, for better utilization and maximum gain from their available local resources and opportunities. Finally, it recommended that counties should embrace governance structures characterized by reduced internal bureaucracy, a balance between centralization and decentralization, and a bulge from rigid orientations to more flexible governance structural systems, which promote accountability in their struggle to attain social and economic development. In assessing the critical role played by governance structures in organizations, Tristan, (2015) observed that they facilitate creation of value through innovation and exploration, and provide control systems commensurate with the risks involved. He emphasized that good governance ensures a fair and transparent business environment, and holds employees accountable for their actions. He concluded that it is only good governance that can deliver sustainable and solid business.

In exercising assigned responsibilities, the devolved structures must observe the Constitution and other relevant laws, policies, procedures and norms which are in place to ensure optimal service delivery for the benefit of stakeholders. Such laws include, The Public Procurement and Asset Disposal Act, 2015, which guides public procurement governance structure; The Public Finance Management Act, 2012, which guides financial governance structure; and The Public Participation Bill, 2018, which gives guidelines for effective public participation. For the human resource governance structure we have Article 232 of the Constitution of Kenya, 2010, on Values and Principles of Public Service, and Chapter 6 on Leadership and Integrity. These emphasize high standards of professional ethics; efficient, effective and economic use of resources; responsive, prompt, effective, impartial and equitable provision of services; transparency and provision to the public of timely, accurate information; fair competition and merit as the basis of appointments and promotions; promote public confidence in the integrity of the office; selection on the basis of personal integrity, competence and suitability; selfless service based solely on public interest, demonstrated by honesty in execution of public duties; accountability to the public for decisions and actions taken; and discipline and commitment in service to the people. All these combined constitute good governance that would result in better health service delivery that is sustainable. Tristan (2015), opined that an effective governance structure should be simple and straight forward, led by an effective executive committee, devoted to aligning all levels of the organization which contribute to achieving the defined strategic goals and objectives. He stated that an institution without governance is like a train without a truck. Unfortunately it took so long for corporate governance to be institutionalized, until the year 2002, when President Bush of the United States of America, signed the Sarbnes - Oxley Act into law that set out enhanced standards for all US public company boards, management and public accounting firms, in order to protect investors.

The Constitution of Kenya provides for three arms of government, namely, the Legislature, the Executive and the Judiciary. At the County Government level, the Executive comprises of the Executive Committee and the County Public Service Board, while the Legislature comprises of the County Assembly, headed by the Speaker. The Judiciary arm of government serves both the National and County Governments with its offices spread all over Kenya. All arms of the County government have a key role to play in service delivery. Among the key roles of the County Assembly which are critical for service delivery include, oversight, making laws, approval of development plans and the Budget, and vetting of appointments. The Executive Committee, under the leadership of the Governor, plays a pivotal role in the formulation and implementation of the county development plan, budgets and programme of activities. The County Public Service Board complements the role of the Executive Committee through identification and appointment of suitable persons for the county public service and advising on Human Resource Management and Development, to ensure provision of effective and efficient services. It is the responsibility of every arm/entity of the county government to put in place measures to ensure effective service delivery and citizen participation in county affairs that affect them.

At the National level, the Legislature, and particularly the Senate plays a critical role in representing and protecting the interests of counties; participating in the law-making function of Parliament by considering, debating and approving Bills concerning counties; determining the allocation of national revenue among counties, and exercising oversight over the same revenue (Republic of Kenya 2010). Among the Commissions which also play a critical role which impacts on service delivery to counties include, the Commission on revenue allocation, whose principal function is to make recommendations concerning the basis for equitable sharing of revenue raised nationally; the Salaries and Remuneration Commission, whose main function is to set and regularly review remuneration and benefits for state officers. It also advises the national and county governments on the remuneration and benefits for all public officers, taking into account the need to ensure fiscal sustainability, attraction and retention of required skills in the public service and recognition of productivity and performance; 
the Ethics and Anti-Corruption Commission whose key role is to fight corruption at both levels of government; The Controller of Budget who is responsible for overseeing the implementation of the budgets of both governments, by authorizing withdrawals from public funds; and the Auditor General whose main role is to audit and report on the accounts of the national and county governments, with a view to ensuring accountability for use of resources availed to both levels of government.

However, the transfer of health services from national to county governments has been marred with challenges, key among them lack of coordination between the two levels of government. Other challenges of devolved governance in the health sector include poor management, ethnicity fears, resource distribution, poor working conditions and delayed salaries for health sector employees (Kimathi, 2017). Reports of health care workers resigning have been rampant so are strikes and strike threats. In Trans Nzoia County, Transparency international (2016) report on the status of service delivery in the health sector indicated that the health sector faced myriad of challenges including low level of public participation and low capacity of management committees. Other challenges reported included; understaffing, delays in supplies, inadequate infrastructure, rampant corruption and mismanagement of funds. The paper examined the extent of implementation of devolved financial resource governance structure and its influence on service delivery in the health sector.

\subsection{Statement of the problem}

Kenya was a highly centralized economy between 1963 and 2010, which resulted in uneven development (World Bank, 2012). The centralized system led to weak, unresponsive and inequitable provision of services, including health (Ndavi et al, 2009). It was noted by Noor et al (2006) that only 63\% of Kenyans had access to government health care facilities located within an hour's travel from their houses. The 2010 constitution of Kenya expected the 47 devolved governments to stimulate innovation in the health system through improved efficiency, effectiveness, access to quality services, and promotion of accountability and transparency in service delivery (Bossert, 1998). The constitution assigned health service delivery to the counties and left policy matters, referral hospitals and capacity building to the national government (Constitution of Kenya, 2010, Schedule 4). The transfer of health services to counties was effected at once, in August, 2013, irrespective of the counties' level of preparedness. The 2010 Constitution, in line with Vision 2030, promised all Kenyans, regardless of their economic status, the highest standards of quality health care service that would be accessible, affordable, available, and acceptable. This is equivalent to provision of Universal Health Services as defined by the World Health Organization (WHO) standards.

The health sector however in nearly all counties in Kenya is bedeviled with monumental challenges ranging from capacity gaps, human resource deficiency, lack of critical legal infrastructure, rampant corruption and a conflicting relationship between County governments and national government (Williamson and Mulaki, 2015). Omondi (2006) observed that there was a slow pace in service provision, inadequate drug supplies, delayed payment of dues, inadequate working equipment, low morale and staff turnover. Wamai (2009) also observed that the government expenditure in the health sector was on a steady decline, from $8.0 \%$ of its GDP in 2001 to $4.6 \%$ in 2010 , despite Kenya's commitment to increase this to $15 \%$, in line with the 1987 Bamoko initiative. The deliberate endeavor by the Government of Kenya to strengthen acquisition and management of medical products, vaccines and technologies by the Kenya Medical Supplies Authority (KEMSA) has not yielded positive results. The paper sought to establish extent of implementation of devolved financial governance structure and its influence on service delivery in public health sector.

\subsection{Research objective}

The study was guided by the following research objective:

1. To establish the influence of devolved financial resources governance structure on service delivery in the public health sector of the County Government of Trans Nzoia, Kenya.

\subsection{Research hypothesis}

The study tested the following null hypothesis:

H0: Implementation of devolved financial resource governance structure does not have significant influence on service delivery in the public health sector of the County Government of Trans Nzoia, Kenya.

\subsection{Justification of the study}

A report by transparency international (2016) pointed out the challenges facing the health care sector in Trans Nzoia County government. Among the challenges included: low levels of public participation, low morale of workers due to poor terms and conditions of service, inadequate medical and support staff, delays in supply of essential service drugs and non-pharmaceutical supplies. This could result in poor service delivery in the public health sector. The current study therefore, investigated the influence of devolved financial governance structure on service delivery in the health sector of the County government of Trans Nzoia. Findings of the study therefore 
informed policy makers on how devolved financial governance structure impacted on service delivery in the health sector.

\subsection{Significance of the study}

Findings of the study provide vital information to the County governments on the extent to which devolved financial structure in the health sector have been implemented. Specifically, the study provides information on the relationship between devolved financial resources governance structure and service delivery in the public health sector. The study also provides important literature to researchers and academicians since devolution is a new concept in Kenya. It will thus help researchers and academicians to generate new knowledge and critique the existing theories.

\subsection{The scope of the study}

This study examined the influence of devolved financial resource governance structure on service delivery in the public health sector of the county government of Trans- Nzoia, Kenya. The study targeted 74 public health facilities because they are funded by the tax payer, have a similar organization structure and are subject to same regulatory framework. The study targeted hospital administrators, doctors, nurses and patient care givers in all the 74 public health facilities of Trans Nzoia County government. The study was conducted in level 2, level 3 and level 4. Level one was left out based on the reason that it was not funded by county governments. Level 5 was not yet in operation when the study was done hence it was difficult to obtain data from the facility.

\subsection{Limitations of the study}

Among the challenges the study encountered was that the geographical area of the study had only one level 5 health facility which was not yet in operation at the time the study was undertaken. Therefore findings and conclusions of the study were based on level 2, level 3 and level 4 health facilities which were in operation. This limits the replicability of the study particularly to a case where level 5 health facilities are involved.

The unit of analysis for the study included health care administrators, doctors, nurses and patent care givers. However in some health facilities particularly level 2 and level 3, some important units of analysis such as administrators and doctors were not there. As a result, the nurses in charge were involved in the study. Furthermore, patients care givers were selected based on their modes of treatment. However, some health facilities lacked the in-patient mode of treatment hence only out-patient care givers were involved.

\subsection{Theoretical framework}

The study was guided by sequential theory of decentralization which was proposed by Falleti (2004), a specialist on issues of federalism, intergovernmental relations and decentralization. The theory contented that decentralization is a set of reforms that aim at transferring responsibilities, resources, or authority from higher to lower levels of system. As such, decentralization does not include transfer of authority to non-state actors (as in the case of privatization reforms). Fallet (2004), "entitled sequential theory of decentralization and its effects on the intergovernmental balance of power" was carried out in Latin America countries of Colombia, Brazil, Mexico and Argentina in 2004. The major conclusion of the theory is that although both critics of decentralization assume that decentralization automatically increases the power and impact of sub-national governments, the extent however varies from substantial to insufficient.

Fallet further concluded that the sequence of different types of decentralization namely financial, administrative and political is a key determinant of the evolution of intergovernmental balance of power. According to the theory, the best results in devolved governance are realized when political reforms are exercised before financial/fiscal, followed by administrative reforms in that sequence. According to the theory, financial decentralization refers to a set of policies designed to increase the revenue or financial autonomy of sub-national governments, the creation of new sub-national taxes, and delegation of tax authority that was previously national. Administrative decentralization comprises of a set of policies which transfers the administration and delivery of social services such as education, health, social welfare or housing to sub-national government, and may include decision making over these policies. The theory has three main characteristics; it defines decentralization as a process, takes into account territorial interests of bargaining actors, and incorporates policy feedback effects in the analysis of bargaining situations, in addition to providing a dynamic account of institutional evolution. Although decentralization can be considered as a set of policy reforms aimed at transferring responsibilities, resources, or authority from higher to lower levels of government, it can also be looked at as a set of reforms which can take place in authoritarian as well as democratic contexts.

Falletti (2004) opined that sequential theory of decentralization classifies territorial decentralization into three categories: organizational, financial and political, depending on the authority involved. Organizational decentralization comprises the set of policies that transfer the organizational and provision of social services such as education, health, social welfare, or housing to sub national governments. Organizational decentralization may 
entail the devolution of decision making authority over these policies, but this is not a necessary condition. Financial decentralization refers to the set of policies designed to increase the revenues or financial autonomy of sub national governments. Financial decentralization policies can assume different institutional reforms such as increase of transfers from the central government, the creation of new sub national taxes, and the delegation of tax authority that was previously national. Political decentralization is a set of constitutional amendments and electoral reforms designed to open new or activate existing dormant or ineffective spaces for the presentation of sub national policies. Political decentralization policies can also be designed and devolved to electoral capacities at sub national level.

\subsection{LITERATURE REVIEW}

Devolved financial governance structure involves mobilizing, allocation and efficient utilization of financial resources for health service delivery. The constitution of Kenya envisages Kenyans to have a right to the highest standards of health service. Devolved financial governance is aimed at ensuring equity, efficiency, transparency and accountability in resource mobilization, allocation and use (MOH, 2014). According to Sun, (2017), financial governance refers to those rules, regulations and procedures that influence how budgetary policy is planned, approved, carried out, monitored and evaluated. Studies have been done on devolved financial resources and service provision in the health sector. For instance, Tsofa, Sassy, Gilson and Goodman (2017) investigated on how decentralization affects health sector planning and financial management in Kilifi County, Kenya. The study established that devolution created an opportunity for local prioritization and community involvement in the health sector planning and budgeting. As a result, this increased opportunities for equity in local level resource allocation. Canada, one of the leading countries in the provision of quality healthcare services, finances $70.9 \%$ of the healthcare costs from public funds, mainly through general taxation. Approximately $15 \%$ is financed through outof-pocket payments by patients and the remainder by supplemental health insurance (Mirit, 2016). Financing of health care services mainly involves three layers. Layer one comprises public services which are financed through general tax revenues and provided free at the point of service in accordance with the Canada health Act. Layer two services are financed through a mix of public and private insurance coverage and out-of-pocket payment and include provision of outpatient prescription drugs, home care and institutional long-term care. Layer three services are financed almost entirely privately and include dental care, outpatient physiotherapy and routine vision care for adults when provided by non-physicians. Approximately $65 \%$ of surveyed Canadians have private supplemental insurance mostly through their employers (Mirit, 2016). This insurance covers some or all of the costs of layer two and three services, notably outpatient prescription medicines, generally with co-payment or deductibles.

According to WHO (2015), the Dutch health system is among the most expensive in Europe, but $91 \%$ of the insured evaluate the health system as good. In the period between 2000 and 2013, the average increase in cost was $5.5 \%$ per year. The healthcare system is principally $(72 \%)$ financed through compulsory health insurance contributions from citizens with an additional 13\% from general taxation. There are two main financing schemes: Curative and long-term care. Financing of the Dutch curative health care system is based on social health insurance. Dutch citizens (Adults) are obliged to purchase health insurance, while health for children under 18 years is paid for by the government. Health insurers and providers negotiate on price and quality of care. Long-term care for persons needing 24-hour supervision is regulated by the long-term care Act and is financed from income development contributions. Home nursing is part of the Health Insurance Act and all other forms of long-term care have been the responsibility of the local government and municipalities.

The Chilean health system is characterized by dual subsystems of public and private health insurance and health care service provision. The mixed health system (public and private) is financed through both public and private funds. Public funds include the state's general budget and tax revenue while private funds include out-ofpocket expenditures and premiums paid for private health plans (Pan American health organization, 2012). The report further indicated that the government of Chile passed comprehensive health legislation in 2005 known as the General regime of Health Care Guarantees. The reform established the explicit guarantee in health care or universal access plan with explicit guarantees. The plan was designed to address health disparities and to target a list of 80 priority diseases and health problems that were selected based on their epidemiological prevalence and public concern, out of which 19 are chronic conditions. The plan specified four basic guarantees of access, quality, opportunity or timelines and financial protection of patients diagnosed with those priority diseases. Ten years into the reform, evaluation findings indicated that there has been substantial increase in access to diagnosis, treatment and coverage in healthcare.

In Kenya, sources of financial resources for the county governments are divided into three; transfer from the national government, locally generated revenue and from the equalization fund from counties which qualify. The 2010 constitution stipulates that not less than $15 \%$ of the total revenue of the national government must be transferred to the county governments (Republic of Kenya, 2010). This should be based on the latest audited national accounts which give the total revenues collected. Locally generated revenue as previously done by local governments include; market fees, parking fees, advertisement fees and approval of building plan fees. They also 
include rent from the county government houses, contributions in Lieu of rates and business permits. County governments adopted structures and financial systems that were previously used by local authorities (Githinji, Okuto and Agembo, 2018). The Revenue Allocation Commission was established by the constitution to advice on financial resource sharing formula between the national government and also among the 47 counties.

A study by Kimathi, (2017), observed that most counties allocated less than 5 per cent of the budget to health. A lot of this allocation went into remuneration of personnel, purchase and improvement of hospital equipment and infrastructure, and purchase of drugs. The low allocation of financial resources has resulted in poor health service provision. However, disbursement of financial resources is not always prompt thus affecting the operations at the county level. According to Miriti and Keiyoro (2017), the major source of financing for the hospital for health facilities was the national government. However, the study findings revealed that finances were not received on time. The commitment of the Government in financing of the health sector is demonstrated by increasing the financial allocations to the health sector and timely release of the funds.

Otieno (2016) carried out a study on resource allocation and implications for equity in Baringo County, Kenya. The study aimed at evaluating resource allocation and its implications to equity. It was found out that although the public finance Act of 2012 was followed in budget making process, there was no criterion or formula for financial resource allocation. There was skewed distribution of human resource personnel with some sub-counties having more than others. There was a significant disparity on the allocation/distribution of health resources across subcounties. Reviewed study provides important information on how resources are distributed in the sub Counties of Baringo County. Due to disparities in the distribution of the resources, service provision may also be affected.

Previous studies have documented on the influence of financial resources on service delivery in the health sector. Wagana, Iravo and Nzulwa (2016) carried out a study to establish effect of financial and political decentralization on service provision in county governments in Kenya. The study findings revealed that financial and political decentralization beneficially affects service provision in county governments in Kenya. Similarly, Otieno, Muriithi and Chuma (2016), evaluated the process of resource allocation to the health sector in Baringo County and its implication to equity. The study was conducted in Baringo County Kenya. Study findings indicated that the average utilization rate of the health services in Baringo county was 1.30 per capita/year which was below the national average rate of 3.1 per capita/year; public finance act of 2012 was followed in the budget making process but there was no criteria or formula for financial resource allocation; there was skewed distribution of the human resources with some sub counties being "favoured" while others were "disadvantaged" and finally there was evident of political interference with the distribution of the health resources. The study recommended immediate redistribution of the available health resources as a short-term measure while formulating and using a need-based resources allocation formula as a medium term and a long-term measure.

Munge and Briggs (2013), examined the progressivity of health-care financing in Kenya. The aim of the study was to analyze progressivity by measuring deviations from proportionality in the relationship between sources of health-care financing and ability to pay using Kakwani indices applied to data from the Kenya Household Health Utilisation and Expenditure Survey (2007). Concentration indices and Kakwani indices were obtained for the sources of healthcare financing, including direct and indirect taxes, out of pocket (OOP) payments, private insurance contributions and contributions to the National Hospital Insurance Fund. The bootstrap method was used to analyze the sensitivity of the Kakwani index to changes in the equivalence scale or the use of an alternative measure of ability to pay. The results of the study indicated that the overall health-care financing system was regressive. Out of pocket payments were regressive with all other payments being proportional. Direct taxes, indirect taxes and private insurance premiums were sensitive to the use of income as an alternative measure of ability to pay. However, the overall finding of a regressive health-care system remained. Byrne (2007) observed that the lengthy budgetary process can also predispose to out-of- date budgets. Top-down budgetary allocation can also be susceptible to political influence and as supplementary estimates can be accessed, managers (and senior clinicians) may not exercise budgetary discipline. Rigid systems of budgeting can also stifle creativity and innovation. Hence, there is a need to link budgeted levels of multi-annual expenditure to recognized and meaningful accomplishment indicators.

\subsection{RESEARCH DESIGN AND METHODOLOGY}

\subsection{Research design}

The study adopted mixed methods research design. Mixed methods design is a type of research in which both qualitative and quantitative research designs and methods are used in combination in a single study to answer the research question.

\subsection{Target population}

The study targeted 663 respondents comprising of health care practitioners and patient care givers from all the 74 public health facilities funded by the taxpayers in the county government of Trans Nzoia. The respondents in the facilities were healthcare managers, providers and patients care givers in the public level 2, level 3, and level 4 
health care facilities in the County government of Trans Nzoia.

\subsection{Sample and sampling techniques}

Stratified random sampling technique was used to select the study sample. All the 74 public health facilities were stratified based on levels then simple random sampling techniques was used to draw a representative sample of health care providers and patients' care givers in each stratum. A total of 331 respondents comprising of 8 administrators, 19 clinical officers, 148 nurses and 148 patient care givers were sampled from the 74 public health facilities for study. Table 3.1 illustrates the sample size of the study.

Table 3.1: The sample size

\begin{tabular}{lllllll}
\hline & Facilities & Administrators & $\begin{array}{l}\text { Doctors/ } \\
\text { CO }\end{array}$ & Nurses & $\begin{array}{l}\text { Patient } \\
\text { Care Takers }\end{array}$ & Total \\
\hline Level 2 & 55 & 0 & 0 & 110 & 110 & 220 \\
Level 3 & 11 & 0 & 11 & 22 & 22 & 55 \\
Level 4 & 8 & 8 & 16 & 16 & 16 & 56 \\
\hline Total & 74 & 8 & 27 & 148 & 148 & 331 \\
\hline
\end{tabular}

\subsection{Data collection instruments}

Data was collected using questionnaires, checklist and document analysis guide. Two questionnaires for health care practitioners and patient care givers were used to collect data for the study. Questionnaire for administrators and service providers were used to obtain data on implementation of devolved governance structures in the public health sector. On the other hand, questionnaire for patient care givers was used to obtain data on service delivery in the public health sector. Orodho, (2005) observed that questionnaires have a major advantage of time efficiency and anonymity. Thus, questionnaires were preferred and also enabled the researcher to reach many respondents at the same time.

\subsection{Validity of research instruments}

The draft instrument was tried out on four public health facilities from the neighboring Bungoma County. All the four hospitals were level four, where all cadres of staff, ranging from nurses to doctors were found. In each hospital, three respondents were selected to answer the questionnaire, making a total of 12 respondents for the pilot. Respondents comprised of hospital administrators, doctors, nurses and patient care givers. Piloting helped to establish if: there were any items in the research instruments that were ambiguous; if there were any problems and complexity that could be encountered during data collection and analysis and if the research instruments were reliable. It also helped to determine whether items in the data collection instruments were clear, appropriate and suitable to the targeted respondents. Responses to the question items in the pilot study were subjected to item analysis to determine whether they were clear to the respondents and whether they measured what they were intended to measure. This helped to improve on validity and reliability of the instruments results by identifying potential problems with the methods, logistics and the data collection instrument itself.

\subsection{Validity of data collection instruments' results}

In order to ensure validity of instrument results, a committee of three research colleagues and two health care practitioners was set up to validate the questionnaire which was the main research instrument for the study. The committee evaluated the questionnaire by checking on clarity of instructions, appropriateness and relevancy of items in the questionnaire in answering the research questions. They also checked on the sequencing of the items, wording of the items and question spacing of the data collection instruments. Items were then corrected in line with the observations of the committee which consisted of supervisors and experts in the field of governance.

\subsection{Reliability of data collection instruments}

Reliability refers to the ability of a measurement instrument to produce the same answer in the same circumstances, time after time (Kothari, 2004). In this study, the reliability was determined using Crownbach Alpha. A reliability score of 0.7 meant that the instrument results are reliable. In this study all the structures had a reliability coefficient of greater than 0.7. Items were therefore reliable.

\subsection{Data analysis procedure}

Data obtained from the field was first sorted, coded and entries keyed in using SPSS program version 21.0. In this study, data was analyzed using both descriptive and inferential statistics. Descriptive statistics involved the use of frequencies, percentages and means while inferential statistics involved use of Spearman correlation, simple and multiple linear regressions. 


\subsection{FINDINGS AND DISCUSSION}

\subsection{Respondents Demographics}

The examined the respondents' demographic data in order to understand how respondents were distributed across the demographic characteristics. The respondents to the study comprised of hospital administrators, doctors, clinical officers, nurses and patient care givers. Demographic data was analyzed using descriptive statistics.

Table 4.1: Distribution of medical personnel by professional qualification

\begin{tabular}{lcc}
\hline Qualification & Frequency & Percent \\
\hline Administrator & 8 & 3.8 \\
Medical doctor & 10 & 4.8 \\
Clinical officer & 43 & 20.7 \\
Nurse & 118 & 56.7 \\
Others & 29 & 13.9 \\
\hline Total & 208 & 100.0 \\
\hline
\end{tabular}

As indicated in Table 4.1, more than half $118(56.7 \%)$ of the study respondents were nurses, $43(20.7 \%)$ were clinical officers while 29 (13.9\%) were others. Among the 29 other medical personnel, there were 10 human resource officers, 2 physiotherapists, 16 laboratory technicians and 1 social worker.

\subsection{Service delivery in the health sector}

The study sought to establish the status of service delivery in the health sector of the county government of Trans Nzoia. Patients' care givers rated the state of service delivery on a five point likert scale. Study findings were as illustrated in Table 4.2.

Table 4.2: Responses on service delivery in the health sector

\begin{tabular}{|c|c|c|c|c|c|c|c|c|}
\hline No. & Statements on service delivery & SA & $\mathrm{A}$ & $\bar{U}$ & $\mathrm{D}$ & SD & Mean & SD \\
\hline & & $\begin{array}{l}\text { Freq } \\
(\%)\end{array}$ & $\begin{array}{l}\text { Freq } \\
(\%)\end{array}$ & $\begin{array}{l}\text { Freq } \\
(\%)\end{array}$ & $\begin{array}{l}\text { Freq } \\
(\%)\end{array}$ & $\begin{array}{l}\text { Freq } \\
(\%)\end{array}$ & & \\
\hline 1. & $\begin{array}{l}\text { Health facilities are closer to } \\
\text { people }\end{array}$ & $23(20.5)$ & $67(59.8)$ & $1(0.9)$ & $15(13.4)$ & $6(5.4)$ & 3.77 & 1.09 \\
\hline 2. & $\begin{array}{l}\text { Drugs are available in health } \\
\text { facilities }\end{array}$ & $4(3.6)$ & $50(44.6)$ & $11(9.8)$ & $34(30.4)$ & $13(11.6)$ & 2.98 & 1.17 \\
\hline 3. & Services are affordable & $16(14.3)$ & $65(58.0)$ & $5(4.5)$ & $21(18.8)$ & $5(4.5)$ & 3.59 & 1.09 \\
\hline 4. & Waiting times are short & $19(17.0)$ & $52(46.4)$ & $4(3.6)$ & $26(23.2)$ & $11(9.8)$ & 3.38 & 1.28 \\
\hline 5. & Enough beds & $7(6.3)$ & $24(21.4)$ & $24(21.4)$ & $30(26.8)$ & $27(24.1)$ & 2.59 & 1.24 \\
\hline 6. & $\begin{array}{l}\text { Prevention \& Vaccination } \\
\text { services available }\end{array}$ & $34(30.4)$ & $69(61.6)$ & $3(2.7)$ & $4(3.6)$ & $2(1.8)$ & 4.15 & .79 \\
\hline 7. & $\begin{array}{l}\text { Prompt response to } \\
\text { emergencies }\end{array}$ & $14(12.5)$ & $70(62.5)$ & $9(8.0)$ & $15(13.4)$ & $4(3.6)$ & 3.67 & .98 \\
\hline 8. & $\begin{array}{l}\text { Health infrastructure improved } \\
\text { after devolution }\end{array}$ & $7(6.3)$ & $54(48.2)$ & $3(2.7)$ & $37(33.0)$ & $11(9.8)$ & 3.08 & 1.21 \\
\hline 9. & $\begin{array}{l}\text { Medical supplies are readily } \\
\text { available }\end{array}$ & $9(8.0)$ & $40(35.7)$ & $10(8.9)$ & $42(37.5)$ & $11(9.8)$ & 2.95 & 1.20 \\
\hline 10. & $\begin{array}{l}\text { Adequate medical personnel } \\
\text { and staff }\end{array}$ & $8(7.1)$ & $33(29.5)$ & $13(11.6)$ & $44(39.3)$ & $14(12.5)$ & 2.79 & 1.20 \\
\hline 11. & $\begin{array}{l}\text { Employees attend to patients } \\
\text { promptly }\end{array}$ & $15(13.4)$ & $74(66.1)$ & $5(4.5)$ & $17(15.2)$ & $1(0.9)$ & 3.76 & .90 \\
\hline 12. & $\begin{array}{l}\text { Patient care services have } \\
\text { improved }\end{array}$ & $11(9.8)$ & $65(58.0)$ & $4(3.6)$ & $28(25.0)$ & $4(3.6)$ & 3.46 & 1.08 \\
\hline 13. & $\begin{array}{l}\text { Staff attend to patients with } \\
\text { courtesy }\end{array}$ & $17(15.2)$ & $78(69.6)$ & $5(4.5)$ & $11(9.8)$ & $1(0.9)$ & 3.88 & .81 \\
\hline 14. & Hospital staff is competent & $18(16.1)$ & $80(71.4)$ & $7(6.3)$ & $5(4.5)$ & $2(1.8)$ & 3.96 & .75 \\
\hline 15. & $\begin{array}{l}\text { Ambulance services } \\
\text { affordable }\end{array}$ & $10(8.9)$ & $57(50.9)$ & $7(6.3)$ & $32(28.6)$ & $6(5.4)$ & 3.29 & 1.14 \\
\hline 16. & $\begin{array}{l}\text { Cleanliness and sanitation has } \\
\text { improved }\end{array}$ & $12(10.7)$ & $69(61.6)$ & $5(4.5)$ & $21(18.8)$ & $5(4.5)$ & 3.55 & 1.06 \\
\hline 17. & $\begin{array}{l}\text { Health facilities linked to } \\
\text { accessible roads }\end{array}$ & $13(11.6)$ & $48(42.9)$ & $7(6.3)$ & $33(29.5)$ & $11(9.8)$ & 3.17 & 1.25 \\
\hline 18. & $\begin{array}{l}\text { Ease of access to medical } \\
\text { specialists }\end{array}$ & $5(4.5)$ & $38(33.9)$ & $10(8.9)$ & $29(25.9)$ & $30(26.9)$ & 2.63 & 1.32 \\
\hline
\end{tabular}




\begin{tabular}{lllllllll}
\hline No. & Statements on service delivery & SA & A & U & D & SD & Mean & SD \\
& $\begin{array}{l}\text { Freq } \\
(\%)\end{array}$ & $\begin{array}{l}\text { Freq } \\
(\%)\end{array}$ & $\begin{array}{l}\text { Freq } \\
(\%)\end{array}$ & $\begin{array}{l}\text { Freq } \\
(\%)\end{array}$ & $\begin{array}{l}\text { Freq } \\
(\%)\end{array}$ & \\
\hline 19. & $\begin{array}{l}\text { Referral services are available } \\
\text { and prompt }\end{array}$ & $12(10.7)$ & $63(56.3)$ & $10(8.9)$ & $23(20.5)$ & $4(3.6)$ & 3.50 & 1.05 \\
Integration of ICT promoted \\
efficiency
\end{tabular}

Study findings on service delivery in the health facilities illustrated in Table 4.2 revealed that the mean rating on whether health facilities were closer enough to where they come from revealed that 20.5 percent strongly agreed, 59.8 percent agreed, 0.9 percent were neutral, 13.4 disagreed and 5.4 strongly disagreed. Findings of the study summed up to a mean of 3.77 which implied that most respondents agreed with the statement. This meant that most of the citizens in Trans Nzoia County have access to public health facilities. The county Government has established health centers in every sub county and dispensaries in every ward. This infrastructure development initiative has ensured access to county health care facilities. This finding is attributable to fruits of devolved governance in the health sector. Accessibility to health services is one of the criterion used by WHO as quality for health services.

When asked on whether drugs are readily available in public health facilities, study findings revealed that 3.6 percent strongly agreed with the statement, 44.6 percent agreed, 9.8 percent were neutral, 30.4 percent disagreed and 11.6 percent strongly disagreed with the statement. The mean rating was 2.98 which was slightly above average thus implying that the respondents who agreed with the statement were almost equal to those who disagreed with the statement. This implied that drugs may be available in some health facilities and others were not well supplied. Drug supplies are perennial challenges faced by most County Governments. It has been difficult to balance demand and supply of drugs due to budgetary allocation deficits and disbursement delays.

Findings of the study on whether medical services are affordable in the public health sector revealed that 14.3 percent strongly agreed with the statement, 58.0 percent agreed, 4.5 percent were neutral, 18.8 percent disagreed and 4.5 percent strongly disagreed with the statement. The mean rating was 3.59 which showed that respondents who agreed with the statement were more than those who disagreed. This implied that medical services in public health facilities are affordable. Access and affordability of devolved health services is one of key objects in the devolved health services. This finding reveals devolution gains experienced by the County Government of Trans Nzoia. Study findings on whether patients are served on time at the health facilities revealed that the 17.0 percent strongly agreed, 46.4 agreed, 3.6 percent were neutral, 23.2 percent disagreed and 9.8 percent strongly disagreed. The mean response rating was 3.38 which implied that more respondents agreed with the statement. This meant that there are no long queues at health facilities. Availability and accessibility of health services enhances service delivery. The public are served as they come and within the time stipulated in the service delivery charter.

Study findings on whether there are enough beds for in-patients in health facilities revealed that 6.3 percent strongly agreed with the statement, 21.4 percent agreed, 21.4 percent were neutral, 26.8 percent disagreed and 24.1 percent strongly disagreed. The findings summed up to a mean rating of 2.59 which was low thus implying that respondents disagreed with the statement. This meant that there were no enough beds for in-patients. This implied that patients may be sharing beds in some health facilities in the County government of Trans Nzoia. More investment is required to increase in-patient absorption capacity. The referral and teaching hospital when completed and operationalized will go a long way to ease congestion in the County health facilities.

On whether prevention and Vaccination services were available for the community, study findings revealed that 30.4 percent strongly agreed with the statement, 61.6 percent agreed, 2.7 percent were neutral, 3.6 percent disagreed and 1.8 strongly disagreed. The mean rating was 4.15 which implied that respondents agreed with the statement. This showed that prevention and vaccination services were available in the public health sector of the County government of Trans Nzoia. Findings of the study on whether there is prompt response to emergencies revealed that 12.5 percent of the respondents strongly agreed with the statement, 62.5 percent agreed, 8.0 percent were neutral, 13.4 disagreed and 3.6 strongly disagreed.Study findings summed up to a mean response rating of 3.67 which implied that most respondents agreed with the statement. This showed that there was prompt response to emergencies in most health facilities. On whether ambulance services were available and affordable, 8.9 percent strongly agreed with the statement, 50.9 percent agreed, 6.3 percent were neutral, 28.6 percent disagreed and 5.4 percent strongly disagreed with the statement. The mean response rating was 3.29 which was above average thus meaning that more respondents agreed with the statement. This meant that ambulance services were available and affordable in public health facilities. The County Government of Trans Nzoia purchased five new ambulances one for each Sub County during the first year of devolution with an objective of prompt response to emergencies. The findings of the study affirm this key achievement by the County government.

Study finding on whether health infrastructure has greatly improved after devolution revealed that 6.3 percent 
strongly agreed with the statement, 48.2 percent agreed, 2.7 percent were neutral, 33.0 percent disagreed and 9.8 percent strongly disagreed with the statement. The overall mean rating was 3.08 which was slightly above average meaning that some respondents agreed and others disagreed with the statement. This could mean that health infrastructure could have improved in some health facilities and not in other health facilities. Since the advent of devolution the County Government has upgraded some health facilities while refurbishing others. However, due to financial constraints, the exercise is yet to cover the whole County.

Findings of the study on whether Medical supplies are readily available revealed that 8.0 percent strongly agreed with the statement, 35.7 percent agreed, 8.9 percent were neutral, 37.5 percent disagreed and 9.8 percent strongly disagreed with the statement. Findings summed up to a mean of 2.95 which implied that the number of respondents who agreed with the statement was higher than those who disagreed. This meant that medical supplies could be readily available in some health facilities and not in other health facilities. On whether there is adequate medical personnel and staff, study findings revealed that 7.1 percent of the respondents strongly agreed with the statement, 29.5 percent agreed, 11.6 percent were neutral, 39.3 percent disagreed and 12.5 percent strongly with the statement. The mean rating was 2.79 which was low thus implying that the medical staff ware not adequate in health facilities. Due to high wage bill, recruitment of health staff has been a tall order. However, critical areas in the health sector are being filled on need basis.

Study findings on whether employees of the health facilities attend to patients promptly revealed that 13.4 percent strongly agreed with the statement, 66.1 percent agreed, 4.5 percent were neutral, 15.2 percent disagreed and 0.9 percent strongly disagreed with the statement. Responses summed up to a mean of 3.76 which was above average implying that many respondents agreed with the statement. This therefore meant that employees of the health facilities attend to patients promptly. The mean rating on whether Patient care services have improved was 3.46 implying that most respondents agreed with the statement. This meant that patient care services had improved after devolution. Study findings on whether hospital staffs attend to patients with courtesy revealed that 15.2 percent strongly agreed with the statement, 69.6 percent agreed, 4.5 percent were neutral, 9.8 percent disagreed and 0.9 percent strongly disagreed. Responses cumulated to a mean rating of 3.88 which was high thus implying that most of the respondents agreed with the statement. This meant that hospital staffs attend to patients with courtesy. On whether the hospital staff is competent, study findings revealed that 16.1 percent strongly agreed with the statement, 71.4 percent agreed, 6.3 percent were neutral, 28.6 percent disagreed and 5.4 percent strongly disagreed with the statement. The mean response rating was 3.96 which implied that respondents agreed with the statement. This meant that clients had confidence in the medical staff in public health facilities in Trans Nzoia County.

Study findings on whether cleanliness and sanitation of hospital facilities had improved revealed that 10.7 percent strongly agreed with the statement, 61.6 percent agreed, 4.5 percent were neutral, 18.8 percent disagreed and 4.5 percent strongly disagreed. The mean rating was 3.5536 which was above average implying that most respondents agreed with the statement. This meant that cleanliness and sanitation of hospital facilities had improved. Study findings on whether health facilities are linked to accessible road networks revealed that 11.6 percent strongly agreed, 42.9 percent agreed, 6.3 percent were neutral, 29.5 percent disagreed and 9.8 percent strongly disagreed. Study findings summed up to a mean of 3.17 which was above average hence implying that most respondents agreed with the statement. However, the mean was to not very high meaning that a high number of respondents also disagreed with the statement. This meant some health facilities were linked to accessible road networks while others were not.

Study findings on whether there was ease of access to medical specialists revealed that 4.5 percent of the respondents strongly agreed, 33.9 percent agreed, 8.9 percent were neutral, 20.5 percent disagreed and 3.6 percent strongly disagreed with the statement. The mean response was 2.63 which indicated that most respondents disagreed with the statement. This implied that medical specialists were not easily accessible to patients. On whether Referral services were available and prompt, study findings revealed that 10.7 percent strongly agreed with the statement, 56.3 percent agreed, 8.9 percent were neutral, 25.9 percent disagreed and 26.9 percent strongly disagreed. Responses summed up to a mean rating of 3.50 which was high indicating that most respondents agreed with the statement. These implied that referral services were available and prompt in public health facilities. Study findings on whether Integration of ICT had made service delivery more efficient revealed that 7.1 percent of the respondents strongly agreed with the statement, 28.6 percent agreed, 15.2 percent were neutral, 16.1 percent disagreed and 33.0 percent strongly disagreed with the statement. The mean response rating was 2.61 which implied that respondents disagreed with the statement. This meant that ICT services had not been effectively integrated in public health facilities in Trans Nzoia County.

The overall mean response rating on service delivery in public health facilities was 3.34. The mean was above average meaning that service delivery in public health facilities was at a fair state. This implied that devolved governance has helped in improving service delivery in public health facilities in the County government of Trans Nzoia. However, there are still areas that need to be improved. Findings of the study were in agreement with those of Makonjo (2017) who reported that devolution had an impact on service delivery in the health sector. Findings 
however disagreed with Mwangi (2018) who established that service delivery was unsatisfactory in Kenyatta National due inadequate integration of ICT in the sector.

\subsection{Implementation of devolved financial resource structure in the public health sector}

The study examined status of implementation of devolved financial resource structure in the public health sector in Trans Nzioa County. A five point likert scale was used to rate the extent of implementation. Responses were rated as indicated: Strongly agree (SA)-5, agree (A)-4, undecided (U)-3, disagree (D)-2 and strongly disagree (SD)-1.

Table 4.3: Responses on implementation of devolved financial resources structure in the public health sector

\begin{tabular}{|c|c|c|c|c|c|c|c|c|}
\hline No. & $\begin{array}{l}\text { Items on devolved financial } \\
\text { resource }\end{array}$ & $\begin{array}{l}\text { SA } \\
\text { Freq } \\
(\%) \\
\end{array}$ & $\begin{array}{l}\text { A } \\
\text { Freq } \\
(\%) \\
\end{array}$ & $\begin{array}{l}\mathrm{U} \\
\text { Freq } \\
(\%)\end{array}$ & $\begin{array}{l}\mathrm{D} \\
\text { Freq } \\
(\%) \\
\end{array}$ & $\begin{array}{l}\text { SD } \\
\text { Freq } \\
(\%)\end{array}$ & Mean & SD \\
\hline 1. & $\begin{array}{l}\text { Composition of budget } \\
\text { committee in line with policy }\end{array}$ & $13(6.3)$ & $62(29.8)$ & $64(30.8)$ & $47(22.6)$ & $22(10.6)$ & 2.99 & 1.10 \\
\hline 2. & $\begin{array}{l}\text { Audit committee is legally } \\
\text { constituted }\end{array}$ & $10(4.8)$ & $65(31.3)$ & $71(34.1)$ & $48(23.1)$ & $14(6.7)$ & 3.04 & 1.00 \\
\hline 3. & $\begin{array}{l}\text { Auditing functions done in line } \\
\text { with financial policy }\end{array}$ & $9(4.3)$ & $57(27.4)$ & $71(34.1)$ & $49(23.6)$ & $22(10.6)$ & 2.91 & 1.05 \\
\hline 4. & $\begin{array}{l}\text { Audit reports available for public } \\
\text { scrutiny }\end{array}$ & $4(1.9)$ & $38(18.3)$ & $58(27.9)$ & $67(32.2)$ & 41(19.7) & 2.50 & 1.06 \\
\hline 5. & $\begin{array}{l}\text { Funds are promptly disbursed for } \\
\text { budgeted products }\end{array}$ & $4(1.9)$ & $34(16.3)$ & $45(21.6)$ & $72(34.6)$ & $53(25.5)$ & 2.35 & 1.09 \\
\hline 6. & $\begin{array}{l}\text { Prudence use of financial } \\
\text { resources }\end{array}$ & $9(4.3)$ & $37(17.8)$ & $52(25.0)$ & $69(33.2)$ & 41(19.7) & 2.54 & 1.12 \\
\hline 7. & $\begin{array}{l}\text { Budget committee ensures } \\
\text { timely implementation of the } \\
\text { health budget }\end{array}$ & $6(2.9)$ & $36(17.3)$ & $49(23.6)$ & $69(33.2)$ & $48(23.1)$ & 2.44 & 1.11 \\
\hline 8. & $\begin{array}{l}\text { Budget committee ensures } \\
\text { timely payment of salaries }\end{array}$ & $4(1.9)$ & $28(13.5)$ & $38(18.3)$ & $71(34.1)$ & $67(32.2)$ & 2.19 & 1.09 \\
\hline 9. & Financial policies adhered to & $4(1.9)$ & $33(15.9)$ & $63(30.3)$ & $67(32.2)$ & $41(19.7)$ & 2.48 & 1.04 \\
\hline 10. & $\begin{array}{l}\text { There is efficient collection of } \\
\text { hospital revenue }\end{array}$ & $5(2.4)$ & $34(16.3)$ & $44(21.2)$ & $70(33.7)$ & $55(26.7)$ & 2.35 & 1.11 \\
\hline & Mean & & & & & & 2.58 & \\
\hline
\end{tabular}

Study findings on implementation of devolved financial resource governance structure in the public health sector, illustrated in Table 4.3, on whether Composition of the budget committee was in line with devolution policy framework, revealed that 6.3 percent strongly agreed and 29.8 percent agreed with the statement. 30.8 percent of the respondents were neutral, 22.6 percent disagreed and 10.6 percent strongly disagreed with the statement. The mean response rating was 2.99 indicating that respondents who agreed with the statement were slightly higher than those who disagreed. This implied that there were those who believed that Composition of the budget committee is in line with devolution policy framework while others did not.

On whether Audit committee is legally constituted, findings of the study revealed that 4.8 percent of the respondents strongly agreed and 31.3 percent agreed with the statement. 34.1 percent of the respondents were neutral, 23.1 percent disagreed and 6.7 percent strongly disagreed with the statement. The mean response rating was 3.04 implying that respondents who agreed with the statement were more than those who disagreed. This meant that majority of the medical personnel believed that the audit committee is legally constituted.

Findings of the study on whether auditing functions are done in line with devolved financial policy framework revealed that 4.3 percent of the respondents strongly agreed with the statement and 27.4 percent agreed. 34.1 percent of the respondents were neutral, 23.6 percent disagreed and 10.6 percent strongly disagreed with the statement. The mean response rating was 2.91 which was slightly above average. From the responses, it was evident that majority of the respondents were either undecided or disagreed with the statement implying that auditing functions were not being done in line with devolved financial policy framework. Study findings on whether audit reports were made available for public scrutiny revealed that only 1.9 percent strongly agreed and 18.3 percent agreed with the statement. 27.9 percent of the respondents were neutral, 32.2 percent disagreed and 19.7 percent strongly disagreed with the statement. The mean response rating was 2.50 which was low thus indicating that most respondents disagreed with the statement. This therefore meant that audit reports are not made available for public scrutiny.

Study findings on whether funds are promptly disbursed for budgeted products and services revealed that 1.9 percent of the respondents strongly disagreed and 16.3 percent agreed with the statement. 21.6 percent of the respondents were neutral, 34.6 percent disagreed and 25.5 percent strongly disagreed with the statement. The mean 
response rating was 2.35 which was low thus indicating that majority of the respondents disagreed with the statement. This therefore implied that funds are not promptly disbursed for budgeted products and services. This could affect service delivery in the health sector. On whether there was prudence use of the scarce financial resources, study findings revealed that 4.3 percent of the respondents strongly agreed and 17.8 percent agreed with the statement. 25.0 percent of the respondents were neutral, 33.2 percent disagreed and 19.7 percent strongly disagreed with the statement. From the study responses, the mean rating was 2.54 which was below average thus indicating that respondents disagreed with the statement. This implied that medical personnel believed that financial resources were not being utilized prudently.

On whether budget committee ensures timely implementation of the health budget, findings of the study revealed that 2.9 percent of the respondents strongly agreed and 17.3 percent agreed with the statement. 23.6 percent of the respondents were neutral, 33.2 percent disagreed and 23.1 percent strongly disagreed with the statement. The mean response rating was 2.44 which was low thus implying that budget committee did not ensure timely implementation of the health budget. This could affect service delivery in the health sector. Study findings on whether budget committee ensures timely payment of salaries to health care workers revealed that 1.9 percent of the respondents strongly agreed and 13.5 percent agreed with the statement. 18.3 percent of the respondents were neutral, 34.1 percent disagreed and 32.2 percent strongly disagreed with the statement. The mean response rating was 2.19 which was low thus indicating that most respondents disagreed with the statement. This implied that budget committee does not ensure timely payment of salaries to health care workers. This could affect the motivation of health care providers which may affect service delivery in the health sector.

Study finding on whether policies guiding receiving and utilization of funds from the national government and other stakeholders are adhered to, revealed that 1.9 percent of the respondents strongly agreed and 15.9 percent agreed with the statement. 30.3 percent of the respondents were neutral, 32.2 percent disagreed and 19.7 percent strongly disagreed with the statement. The mean response rating of was 2.48 which was low indicating that respondents disagreed with the statement. Study findings on whether there is efficient collection of hospital revenue revealed that 2.4 percent of the respondents strongly disagreed and 16.3 percent agreed with the statement. 21.2 percent of the respondents were neutral, 33.7 percent disagreed and 26.7 percent strongly disagreed with the statement. The mean response rating was 2.35 which was low thus implying that respondents disagreed with the statement. This implied that health care service providers opined that there is no efficient collection of hospital revenue. This could negatively affect service delivery in the health sector.

The overall mean rating on implementation of devolved financial resources was 2.58 . The mean was moderate implying implementation of devolved financial resources structure was not fully realized. Findings were in tandem with respondents on open ended items. For instance, majority of the respondents indicated that devolution had not lately resulted in increased allocation of financial resources to health facilities. Lack of proper prioritization, financial accountability, inadequate financial resources and delayed disbursements affected implementation of devolved financial governance structure. This gives credence to the statement made by the Chairman of the Council of Governors, His Excellency Wycliffe Oparanya, in October 2020, that "delays in funds disbursements to counties have been a perennial problem since inception of counties. These have often grounded operations in counties to a halt, adversely affecting payment of staff salaries, which often remain unpaid for months. County creditors are also not paid on time and project implementation often stopped. Consequently, Service delivery has been seriously affected. This has raised serious questions on long-term sustainability of counties." Total reliance on the exchequer has taught counties that they must explore alternative ways of financing their operations. It is recommended that a study be carried out to find out the root cause of the problem and ways of financing capital projects and operating expenses.

Findings of the study agreed with the findings of Otieno (2016) who carried out a study on resource allocation and implications for equity in Baringo County, Kenya. It was found that the Public Finance Act of 2012 was followed in budget making process but there was no criterion or formula for financial resource allocation within the county. There was skewed distribution of financial resources with some sub-counties being favoured while others are being disadvantaged. There was a significant disparity on the allocation/distribution of health resources across Counties. Reviewed study provides important information on how resources are distributed in the sub Counties of Baringo County.

\subsection{Relationship between implementation of devolved financial resource governance structure and service delivery in the health sector}

The study sought to establish the relationship between implementation of devolved fiscal resource structure and service delivery in the health sector. Non - parametric spearman correlation test was carried out to establish the correlation between implementation of devolved fiscal resources structure and service delivery in the health sector. The study tested the null hypothesis that there is no significant relationship between implementation of devolved fiscal resources structure and service delivery in the public health sector of the County Government of Trans Nzoia, Kenya. Study findings were as illustrated in Table 4.4. 
Table 4.4: Correlation between implementation of devolved financial resource governance structure and service delivery in the health sector

\begin{tabular}{ll}
\hline Variable & Fiscal resources \\
\hline Health service delivery & rho $=0.825$ \\
& $\mathrm{p}<0.001$ \\
\hline
\end{tabular}

Study findings revealed that that the P-value (0.001) was less than 0.05 level of significance. The study therefore rejected the null hypothesis that there is no significant relationship between implementation of devolved fiscal resources structure and service delivery in the public health sector of the County Government of Trans Nzoia, Kenya. This led to a conclusion that there is a significant relationship between implementation of devolved fiscal resource structure and service delivery in the health sector.

\subsection{Regression test between implementation of devolved financial resource governance structure and service delivery}

Simple linear regression test was performed to establish whether implementation of devolved fiscal resource structure was a major factor in the service delivery in the health sector, regression analysis was performed. Results were as illustrated in Table 4.5.

Table 4.5: Model summary- devolved fiscal resource structure and service delivery

\begin{tabular}{cccc}
\hline $\mathrm{R}$ & $\mathrm{R}$ Square & Adjusted R Square & Std. Error of the Estimate \\
\hline $.839 \mathrm{a}$ & .705 & .700 & 4.91835
\end{tabular}

a. Predictors: (Constant), Fiscal Resources

Findings revealed that the R Square value was .705, which indicated that $70.5 \%$ of the variance in the service delivery is explained by the fiscal resources in the current study. This implied that devolved fiscal resource structure was a strong predictor of service delivery in the health sector. Table 4.6: Regression model

\begin{tabular}{|c|c|c|c|c|c|c|c|}
\hline \multirow[t]{2}{*}{ Model } & \multicolumn{2}{|c|}{$\begin{array}{l}\text { Unstandardized } \\
\text { Coefficients }\end{array}$} & \multirow{2}{*}{$\begin{array}{c}\text { Standardized } \\
\text { Coefficients } \\
\text { Beta }\end{array}$} & \multirow[t]{2}{*}{$\mathrm{T}$} & \multirow[t]{2}{*}{ Sig. } & \multicolumn{2}{|c|}{$\begin{array}{l}\text { 95\% Confidence } \\
\text { Interval for B }\end{array}$} \\
\hline & B & $\begin{array}{l}\text { Std. } \\
\text { Error }\end{array}$ & & & & $\begin{array}{l}\text { Lower } \\
\text { Bound }\end{array}$ & $\begin{array}{l}\text { Upper } \\
\text { Bound }\end{array}$ \\
\hline (Constant) & -9.595 & 4.812 & & -1.994 & .050 & -19.188 & -.002 \\
\hline Fiscal Resources & 2.607 & .199 & .839 & 13.103 & .000 & 2.211 & 3.004 \\
\hline
\end{tabular}

a. Dependent Variable: Service delivery

The $p$-value in the model is statistically significant $(p<0.001)$. This implies that implementation of devolved fiscal resources structure is a predictor of service delivery in the health sector. This meant that implementation of devolved fiscal resource structure is a significant predictor of service delivery in the health sector. Findings of the study agreed with the findings of Tsofa, Sassy, Gilson and Goodman (2017) who investigated on how decentralization affects health sector planning and financial management in Kilifi County, Kenya. The study established that devolution created an opportunity for local prioritization and community involvement in the health sector planning and budgeting. As a result, this increased opportunities for equity in local level resource allocation. Similarly, study findings also agreed with the findings of Wagana, Iravod Nzulwa (2016) who carried out a study to establish effect of financial and political decentralization on service delivery in county governments in Kenya. The study findings revealed that financial and political decentralization positively affects service delivery in county governments in Kenya.

\subsection{Conclusions}

Study findings indicated that implementation of devolved financial structure statistically influences service delivery in the health sector in Kenya. The study concluded that devolution of the financial governance structure was statistically significant in explaining service delivery in health sector in Kenya. Therefore, county governments that have adequately implemented devolved governance structure will result to efficient service delivery in the health sector.

\subsection{Recommendations}

Based on the findings and conclusions of the study, the study recommended for adequate revenue allocation, timely disbursement and own revenue generation by county governments. The study also recommended for annual audits to ensure effective and efficient use of financial resources. Health facilities should also be encouraged to device new methods of raising financial resources. The budgeting, planning and procurement of goods and services and accounting for the same should to a certain level be left to facility employees.

The study also recommended for a policy to guide disbursement of financial resources from the consolidated fund to county governments. This will ensure adequate and timely disbursement of financial resources. The policy 
should also guide the basis for revenue allocation formula. A policy should also be formulated to guide allocation of financial resources at county level. This will guide on capital and operations expenditure at the county level. The study also recommended for a policy to coordinate the partnerships between non-governmental organizations and the public sector.

\section{References}

Bashir, Y. M. (2016), an Assessment of the Impact of Government Expenditure on Infrastructures: Evidence from Nigerian Health Area Accomplishment, European Journal of Business and Management, Vol.8, No.14, 2016

Byrne, M. (2007), the usefulness of budgets in the Healthcare area, Irish Journal of Management, 27(2), 67-73.

Dasgupta, A., Victoria, A.B (2007). Community driven development, collective action and elite in Indonesia. Development change, 38 (2), 229-249

Falleti G.T (2004). A sequential theory of decentralization and its effects on: The intergovernmental balance of power: Latin American cases in comparative perspective. Working paper, Kellogg Institute.

Kim, A (2008). Decentralization and the provision of public services: Framework and Implementation.

Kimathi, L. (2017). Challenges of the Devolved Health Area in Kenya: Teething Problems or Systemic Contradictions, Africa Development, Volume XLII, No. 1, pp. 55-77

Kinyanjui, M. (2019). Environmental factors and health care service delivery under the devolved system in Kenya: A case study of level 5 hospitals in Kiambu County. International Journal of economics, commerce and management, Vol. 7(12), December, 2019

Kothari, C. R. (2004) Research methodology, New Delhi; Vikes Publishing House

Makonjo, G.T (2017). The impact of devolution on health care systems: A case study of Nairobi County health facilities.

Miriti, A.K \&Keiyoro, P. (2017), influence of devolution of government service provision on provision of healthcare: a case of level five hospital in Meru County, Kenya, International Academic Journal of Information Sciences and Project Management, Volume 2, Issue 1, pp. 300-315

Miriu, A.R (2012). Decentralization, citizen participation and local public service provision. (Masters), Universitatsverlag Potsdam

Munge, K. \& Briggs, A. H. (2013), The progressivity of health-care financing in Kenya, Oxford University Press, London.

Muriel, V. V. \& Mariam, B. U. (2010), “Area Budget Support in Practice: Case Study Health Area in Mozambique”, Overseas Development Institute, London

Mwangi, B.M (2017). Factors influencing adoption of ICT strategy in the Kenyan public health sector. A case study of the Kenyatta national hospital. Published thesis, United States International University- Africa

Orodho, J.A. (2005). Elements of Education and Social Science Research Methods.Masola Publishers, Nairobi.

Otieno, M, Chumo, J \&Murithii, M. K. (2016), Resource allocation to health area at the county level and implications for equity, a case study of Baringo County, University of Nairobi Repository.

Ozmen, A. (2014). Notes to the concept of decentralization. European scientific journal, 10(10)

Sun, M. (2017). Utility, pitfalls and perils of using public databases for RCC research. Presented at: International Kidney Cancer Symposium; Nov. 3-4, Miami.

Triesman, D (2007). The architecture of government. Rethinking political decentralization, Cambridge: Cambridge university press.

Tsofa, B., Goodman, C., Gilson, L., \&Molyneux, S. (2017). Devolution and its effects on health workforce and commodities management - early implementation experiences in Kilifi County, Kenya. International Journal for Equity in Health, 16, 169.

Wagana, D.M, Iravo, M.A \&Nzulwa, D.J (2016). Effect of financial and political decentralization on service provision in county governments in Kenya. International Journal of academic research in business and social science, Vol6, N.o 6, June, 2016

Wamai, R. G. (2009), The Kenya Health System-Analysis of the situation and enduring challenges, International Medical Community, Vol. 52, No. 2

Williamson, T. \&Mulaki, A. (2015), “Devolution of Kenya's health system the role of HPP”, Health Policy Project, USAID, Nairobi 